\title{
Correlates of district-level turnout in Vienna: What role does electoral exclusion play?
}

Jeremias Stadlmair

Department of Political Science, University of Vienna

jeremias.stadlmair@univie.ac.at

\begin{abstract}
With an increasing share of voting-age residents without Austrian citizenship, Vienna is a striking example of a boundary problem of electoral participation. Without Austrian citizenship comes an exclusion from electoral rights at national, regional and, for some, also at European elections. The paper examines turnout rates and their socio-demographic covariates for II elections on the aggregate level of districts in Vienna, Austria, from 2004 to 2019. The analysis shows that aggregate turnout is statistically associated with socio-economic district characteristics, diversity within the electorate and the proportion of individuals not eligible to vote. To conclude, the paper discusses possible mechanisms behind the correlation of electoral exclusion and turnout and provides perspectives for further empirical tests of such mechanisms.
\end{abstract}

\section{Keywords}

turnout, citizenship, electoral rights, participation, election

\section{Elektoraler Ausschluss von nicht-österreichischen StaatsbürgerInnen und Wahlbeteiligung in Wien}

\section{Zusammenfassung}

Mit einem zunehmenden Anteil nicht wahlberechtiger WohnbürgerInnen stellt die Stadt Wien ein Paradebeispiel für das Boundary-Problem politischer Partizipation dar, in dem das Wahlrecht auf regionaler, nationaler und teilweise europäischer Ebene an die Staatsbürgerschaft geknüpft ist. In diesem Beitrag wird die Wahlbeteiligung in Wiener Gemeindebezirken in elf Wahlgängen von 2004 bis 2019 im Hinblick auf das sozio-ökonomische Profil, Migrationshintergrund und Wahlrecht der BezirksbewohnerInnen untersucht. Die Ergebnisse der Aggregatdatenanalyse zeigen einen statistischen Zusammenhang zwischen Wahlbeteiligung und sozio-ökonomischen Ressourcen, Diversität innerhalb des Elektorats und dem Ausmaß rechtlichen Ausschlusses der EinwohnerInnen vom Wahlrecht. In der Conclusio wird ein möglicher Ansteckungseffekt diskutiert, in dem (Nicht-)Wählen als sozialer Akt auch dadurch geprägt ist, ob Menschen in der Umgebung über ein Wahlrecht verfügen oder nicht.

\section{Schlüsselwörter}

Wahlbeteiligung, Staatsbürgerschaft, Wahlrecht, Politische Partizipation, Wahlen

The author has declared that no competing interests exist. 


\section{Introduction}

Due to high levels of immigration and exclusive citizenship laws, the proportion of residents with foreign citizenship is increasing in several European countries, which contributes to a democratic deficit in form of an incongruence between those entitled to participate and those affected by decisions made in a polity (Pedroza 2015; Blatter et al. 2017; Bauböck 2018). When assessing the input-legitimacy of elections, it is therefore not sufficient to focus on turnout rates alone. Instead, it is necessary to also take electoral inclusion/exclusion into account in order to make statements about the degree to which the resident population participates in elections (Wigginton et al. 2020).

This paper builds upon previous research on socio-economic marginalisation and immigration and their implications for turnout (Schäfer et al. 2013; Bellettini et al. 20I4; Förster 20I8; Ruedin 2018) by adding electoral exclusion to models explaining aggregate turnout. The divergence between resident population and electorate is particularly pronounced in Vienna as a result of exclusive (national) citizenship laws and high immigrant inflows, which have led to a rate of 29 per cent foreign citizens in the voting-age population of $\mathrm{Vi}$ enna in 2019, 13 per cent of whom are EU citizens and I6 per cent third-country nationals. With its division into 23 districts with varying socio-demographic profiles, Vienna presents an ideal case study for an analysis of spatial patterns of turnout across districts. As the analysis builds on aggregated data, direct inferences on the individual level are not possible. However, the analysis identifies a need to further explore implications of electoral exclusion on turnout: Since voting is per se a social act (Bhatti/Hansen 2012), a widespread lack of voting rights may have negative effects on the turnout of those who are entitled to vote.

\section{State of the Art}

As famously argued by Lijphart (1997), low turnout poses a challenge for democracy as it implies unequal turnout, in particular with regard to social class. In a hypothetical case of full participation, full proportionality and one vote per person, all eligible citizens would have equal power in elections. However, since there is no full turnout, we may assume that some societal groups participate more and others less, which is visible inter alia in spatial clusters. In other words, voters and non-voters are not distributed randomly across space.

Many studies on electoral participation highlight the relevance of spatial context for participation. Following a general rationale that political participation is a social act driven by interactions and networks (Verba et al. 1995; Bhatti/Hansen 20I2; Fieldhouse/Cutts 20I2; Siegel 2009; Nickerson 2008), which take place in geographic space, (non-)participation may also have an indirect effect on the participation of one's neighbours and social environment. While most studies on such a "contagion effect" focus on the household level (Vonnahme 2012; Straits 1990; Bhatti/Hansen 2012), others stress the importance of social norms of voting (Gerber et al. 2008), social embeddedness in the neighbourhood (Förster 2018) or neighbourhood design (Hopkins/Williamson 2012). As such, there is a growing literature investigating spatial differences in participation and their macro-, meso-, and micro-level determinants (Cho/ $\mathrm{Ru}$ dolph 2008; Schäfer et al. 2013; Schäfer 2013; Bartle et al. 2017; Cancela/Geys 2016; Geys 2006). Of these factors, socio-economic characteristics and immigration or ethnic diversity in the neighbourhood were found to be relevant predictors of turnout (Schäfer et al. 2013; Bellettini et al. 20I4; Bartle et al. 2017; Förster 2018). Since electoral exclusion qua citizenship and socio-economic marginalisation tend to intersect, it is necessary to include indicators of socio-economic marginalisation as complementary factors in the analysis of enfranchisement and turnout. As such, district-level unemployment and income data are used to account for socio-economic marginalisation.

Importantly, such spatial patterns cannot be fully attributed to social networks alone, but even persist in analyses which control for formal interaction processes. Therefore, Cho and Rudolph (2008) suggest also considering very subtle ways of interaction, such as observation and imitation. In this perspective, the participatory behaviour of neighbours shapes one's own participation, without necessarily requiring in-depth interaction or formal networks. Unlike the current scholarship on spatial patterns of turnout, which focuses on individuals who can - but do not - vote, this paper examines whether those who cannot vote because of their citizenship matter for the turnout of those who can. On the example of turnout rates in Viennese districts, it tests whether there is a contagion effect of electoral exclusion.

For aggregate-level studies on turnout, it is problematic to distinguish between a mere aggregation of individual-level factors for participation at neighbourhood or district levels and a genuine spatial effect of socio-demographic characteristics of neighbourhoods or districts (Bartle et al. 2017; Smets/van Ham 2013). For instance, aggregate turnout levels may be related to unemployment rates simply due to the presence of unemployed residents with a lower probability to vote, or by an effect of the presence of unemployed residents on their neighbourhood (Cho/Rudolph 2008; Schäfer et al. 20I3). To be sure, whether it is possible to make any inferences at individual level when relying solely on aggregated data is contested in social science research 
(Geys 2006, 64I; Hudson et al. 20I0; King 1997). Thus, the paper provides a rough test on the correlations of turnout and electoral exclusion of co-residents, but it requires further research combining macro- and microlevel data on how such a mechanism might work.

\subsection{Immigration and Electoral Exclusion}

At the individual level, there are various explanations for lower turnout rates of people from migrant backgrounds, such as less interest in the politics of the country of residence, differences in socialisation, or fewer networks and less knowledge about opportunities to participate (Street 20I7; Bird et al. 20II; Just/Anderson 2012; Ruedin 20I8; Cho 1999). Assuming that incentives to participate are not limited to an individual, but function in a neighbourhood context via casual observation and imitation (Cho/ Rudolph 2008), a greater share of immigrants in the resident population should lead to lower turnout. As such, living in a neighbourhood with a larger proportion of non-enfranchised or non-voting neighbours might make it less likely that people vote who might vote in another neighbourhood context, visible in aggregate turnout differences. Research on aggregate turnout has shown that neighbourhoods with higher levels of immigrants have indeed lower turnout (Bellettini et al. 2014): In addition, Förster (2018), on the case of German national elections, shows that individual (reported) turnout is lower in areas with a higher proportion of foreign residents even when controlling for a broad range of individual-level factors influencing turnout. Importantly, Förster finds an effect of foreign residents on turnout at a very narrow neighbourhood level of square kilometre grids, but not on the level of German districts. Hence he concludes that "the effects are specific to sufficiently narrow measures of geographic locations" (Förster 2018, 6I). These findings support an argument that electoral exclusion might matter for turnout, but require further empirical scrutiny in terms of competing explanations for aggregate turnout levels, the level of analysis and the role of enfranchisement rules, such as citizenship and electoral laws.

First, it is unclear whether immigrants within the electorate are the driver of spatial turnout differences or the presence of foreign citizens, who are not entitled to vote. Belletini et al. (2OI4) and Förster (2018) rely on a measurement of the latter, but cannot specify whether ethnic diversity (regardless of citizenship status) or electoral exclusion (dependent on citizenship status), or both are the main driving factor behind lower turnout in areas with higher shares of foreign citizen residents. In order to make this distinction, I include measures for diversity within the electorate (percentage of foreign-born voting-age Austrian citizens) and for residents outside the electorate (percentage of non-enfranchised voting-age residents).
Second, the electoral boundaries vary across different election types (Arrighi/Bauböck 20I7). If electoral exclusion functions as a disincentive to vote in a neighbourhood context, such an effect should be weaker in elections with inclusive eligibility rules, while an effect of diversity within the electorate might be stronger in more inclusive (and therefore more diverse) electorates. Hence the effect of electoral exclusion should be weaker in European elections, where EU citizens are entitled to vote.

Third, a focus on cities may be more suitable to scrutinize the role of electoral exclusion and diversity for turnout, because it is mainly cities which have to deal with electoral implications of diversity and immigration (Stadlmair 2018). Consequently, it is necessary to complement findings on quasi-random neighbourhoods with greatly varying population density (Förster 2018) with studies focused on neighbourhoods with high population density and varying socio-demographic structures (Bellettini et al. 20I4).

\section{Citizenship and Elections in Vienna}

Vienna has an unusually high percentage of foreign citizens among its residents, a result of continuing immigration and exclusionary citizenship laws towards immigrants. Responding to the electoral implications of this development, attempts were taken in the past to facilitate the naturalisation of foreign residents and to extend electoral rights at the regional level to foreign citizens (Stadlmair 2018). However, both approaches to the electoral inclusion of these residents failed due to a ruling of the constitutional court in 2003 that forbade the extension of voting rights to foreign citizens. In addition, a citizenship reform at federal level in 2006 curtailed the discretion of regional authorities in the processing of naturalisation applications (Bauböck/Perchinig 2006a). Electoral rights at the regional and national levels remain limited to Austrian citizens while European elections are open to EU citizens (including Austrian citizens, of course; Stern/Valchars 2013). The proportion of foreign residents has continued to grow, reaching 29 per cent of the voting-age population in 2019.

In addition to changes in citizenship legislation and the constitutional court ruling preventing an extension of electoral rights to non-Austrian citizens, the electoral system was amended in terms of the minimum voting age and postal voting: In a federal reform of 2007 , the active voting age was lowered from I8 to 16 years, which applies to all elections held in Austria (already in place in the Viennese regional elections in 2005). This reform does not seem to have had a substantial impact on turnout, as I6-I8 year-old citizens seem to participate at about an average level (Zeglovits/Aichholzer 20I4). The reform 
of postal voting, however, may have brought an increase in turnout and potentially a greater social stratification of turnout, as postal voting tends to be used particularly by individuals with higher education and income and younger people (Poier 2009). Thus institutional factors may have caused slightly higher turnout levels from 2007 and simultaneously also greater social stratification. Apart from institutional settings, changes in turnout may also result from increased party system fragmentation and competition, especially at national level (Wineroither/Kitschelt 2012; Bodlos/Plescia 2018; Dolezal/Zeglovits 20I4). For Viennese regional elections, the 2015 election was framed as a competition between Michael Häupl (SPÖ) and Heinz-Christian Strache (FPÖ) for the office of Mayor of Vienna, which may also have triggered an unusually high turnout. To sum up, policy changes aimed at increasing electoral participation, in conjunction with increasing party system fragmentation and close election outcomes, may serve as an explanation for slightly increased turnout over time (see Table 3 below).

\section{Data and Methods}

Turnout is measured as voting-eligible population (VEP) turnout (Wigginton et al. 2020), which does not take the issue of a substantial proportion of foreign residents into account and is the default way of reporting turnout in Austrian elections. This measure of turnout is aggregated at the level of Viennese districts.

Electoral exclusion is measured by the percentage voting-age residents with no voting rights at district level because they lack Austrian citizenship. Except for European elections, this measure is composed of third-country nationals and EU citizens. Following the distinction between electoral exclusion and immigrant (non-)voters as outlined above, a separate measure focuses on immigrants within the electorate. As such, the percentage of voting-age Austrian citizens born outside Austria is taken as a measure for immigration-related diversity within the electorate. To be sure, this indicator includes naturalised individuals as well as those who were Austrian citizens from birth but were born outside Austria. It does not - unfortunately -include foreign citizens who were born in Austria and naturalised since.

The degree of economic marginalisation of Viennese districts is measured by their unemployment rates in the population aged 16 to 64 , median income of employees, and percentage of residents with mandatory education only. As these items correlate substantially (Table I), a principal component analysis suggests only one dimension, therefore these items are merged into a (z-standardised) index. Information on home ownership and other income percentiles would be valuable additions to the items described above, but are available only rarely for the district level in Vienna (Caren 2007; Bartle et al. 20I7; Geys 2006).

Table 1: Pearson's $r$ correlations of main items of interest

\begin{tabular}{|c|c|c|c|c|c|}
\hline & 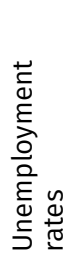 & 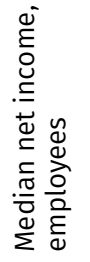 & 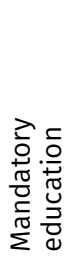 & 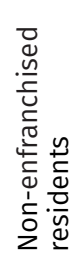 & 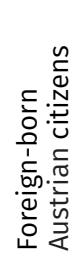 \\
\hline Unemployment rates & 1 & & & & \\
\hline $\begin{array}{l}\text { Median net income, } \\
\text { employees }\end{array}$ & 0.87 & 1 & & & \\
\hline Mandatory education & 0.96 & 0.91 & 1 & & \\
\hline $\begin{array}{l}\text { Non-enfranchised } \\
\text { residents }\end{array}$ & 0.54 & 0.72 & 0.57 & 1 & \\
\hline $\begin{array}{l}\text { Foreign-born } \\
\text { Austrian citizens }\end{array}$ & 0.81 & 0.79 & 0.87 & 0.59 & 1 \\
\hline
\end{tabular}

Note: all variables are $z$-standardised per election (group mean centred); First district excluded; $\mathrm{N}=242$, except for mandatory education ( $N=154) ;$ Author's own calculation; Data: Stadt Wien and Statistik Austria;

In addition to indicators on diversity within the electorate, electoral exclusion and socio-economic marginalisation, I also included the proportion of left-wing voters, age groups, population size and population mobility as controls at district level to provide a more comprehensive socio-demographic view on aggregate turnout (Geys 2006; Cancela/Geys 2016; Hooghe/Kern 20I7; Wilford 2019; Vallbé/Magre Ferran 2017). These are necessary to account for to get a clear picture of the distinct relevance of electoral exclusion and immigration on turnout, since citizenship intersects with age and unemployment as well as with district size and mobility (Wass et al. 2015). Left-wing votes are measured by the share of Green and SPÖ voters out of all valid votes for each election. To account for different age compositions across districts, I include an indicator on the rate of residents aged 65+ years. Population size is logged. Population mobility is measured as the sum of migration to and from a district into a foreign country or another Austrian region, divided by the total number of residents per district and year. Table 2 provides summary statistics of all variables used to examine aggregate turnout. All data were collected from the Annual Statistical Reports of the City of Vienna (Statistisches Jahrbuch der Stadt Wien, 2004-2017) and the Statcube application of STATISTIK Austria.

The analysis proceeds in two steps: First, aggregate turnout levels and their correlation with socio-economic marginalisation, diversity within the electorate and electoral exclusion are examined descriptively across 
Table 2: Summary statistics

\begin{tabular}{|c|c|c|c|c|c|c|c|c|c|}
\hline & Min & P25 & P50 & P75 & Max & Mean & SD & $\mathrm{N}$ & Year \\
\hline District turnout & 30.24 & 52.52 & 66.15 & 71.9 & 81.53 & 62.12 & 13.47 & 253 & 2004-2019 \\
\hline $\begin{array}{l}\text { Residents aged } \\
65+\text { years }\end{array}$ & 11.41 & 14.82 & 15.62 & 17.82 & 25.49 & 16.70 & 3.17 & 253 & 2004-2019 \\
\hline Population size & 9.57 & 10.50 & 11.04 & 11.26 & 12.04 & 10.90 & 0.58 & 253 & 2004-2019 \\
\hline Population mobility & 4.33 & 7.27 & 9.68 & 11.48 & 29.37 & 10.04 & 4.12 & 253 & $2004-2019^{*}$ \\
\hline Left-wing votes & 31.37 & 47.02 & 52.13 & 58.60 & 68.32 & 52.24 & 8.14 & 253 & 2004-2019 \\
\hline $\begin{array}{l}\text { Foreign-born } \\
\text { Austrian citizens }\end{array}$ & 8.63 & 11.56 & 12.80 & 14.31 & 16.64 & 12.92 & 1.78 & 253 & 2004-2019 \\
\hline TCN residents & 4.99 & 10.67 & 12.73 & 17.44 & 25.45 & 13.71 & 4.75 & 253 & 2004-2019 \\
\hline EU residents & 2.26 & 5.63 & 8.41 & 11.95 & 18.31 & 8.95 & 4.16 & 253 & 2004-2019 \\
\hline Non-eligible residents & 4.99 & 14.10 & 20.43 & 26.08 & 41.65 & 20.55 & 8.01 & 253 & 2004-2019 \\
\hline Unemployment rates & 2.62 & 5.70 & 7.28 & 9.11 & 16.29 & 7.62 & 2.74 & 253 & 2004-2019* \\
\hline $\begin{array}{l}\text { Median net income, } \\
\text { employees** }\end{array}$ & 79.09 & 90.63 & 105.22 & 113.12 & 161.56 & 104.45 & 16.31 & 253 & 2004-2019* \\
\hline Mandatory education & 8.88 & 14.48 & 19.86 & 26.93 & 35.18 & 20.72 & 7.04 & 161 & $2008-2017$ \\
\hline
\end{tabular}

* 2019 values not available at time of analysis (Spring 2020), used 2018 instead

** Standardised variable with $100=$ median annual net income of employees across Vienna

Note: Author's own calculation; Data: Stadt Wien and Statistik Austria

districts. All variables were z-standardised for each election (group mean centering) to examine differences in district turnout within elections (Wenzelburger et al. 2OI4, IO3-IO4).

In a second step, hierarchical regression analyses with districts nested in elections are conducted to see if these correlations still hold when controlling for other covariates. The models cover eleven elections ( 3 regional elections, 5 national elections, 3 European elections) and 22 districts, leading to a total of 242 observations. The first district of Vienna was excluded from the analysis, because it is fairly small and differs greatly from other districts in terms of income and citizenship. Models excluding the first district seem more adequate, yet face a bias of deliberately excluding observations from the analysis. Unless specified otherwise, the models include group mean centred, z-standardised predictors and random intercepts for each election. Additional analyses include random slopes for the main independent variables of interest (see Table 4), include the first district, use raw data and confirm the main findings (see Table 5).

\section{Analysis}

Table 3 displays the turnout levels in the 23 Viennese districts for the past eleven elections. With two exceptions (2013 and 2019 national elections), they show an increase in average turnout for each election type over time, against a European trend of decreasing turnout (Hooghe/Kern 2017). As mentioned above, there are some good reasons for increased turnout in recent elections, such as the introduction of postal voting, party system fragmentation and (at least expected) close election outcomes (Poier 2009; Dolezal/Zeglovits 20I4; Bodlos/Plescia 2018). Despite these average increases in electoral participation, differences between districts became larger over time, indicated by standard deviations in Table 3. These basic descriptive findings point at the greater relevance of spatial context for electoral participation and suggest - in line with Förster (2018) - that diversity and electoral exclusion may have become more relevant for turnout in recent elections.

Turning to potential covariates of aggregate turnout, bivariate analyses reveal that turnout is statistically correlated with indicators on economic marginalisation, education and migration-related diversity at district level, as indicated in Figure I. Turnout is clearly higher in contexts of higher median incomes and low unemployment (Pearson's r: .89, significant at $\mathrm{p}<$.ooI) and in contexts of lower proportions of residents with only mandatory education (Pearson's r: .9I, significant at $\mathrm{p}<$.ooI). Furthermore, districts with a higher percentage of foreign-born Austrian citizens present lower turnout (Pearson's r: .85, significant at $\mathrm{p}<$.0oI). The correlation between the percentage of voting-age non-enfranchised residents and turnout is weaker, yet still substantial with a Pearson's $r$ of .60 (significant at $\mathrm{p}<$.0oI). All indicators were $\mathrm{z}$-standardised per election to obtain comparability across elections. As indicators on economic marginalisation and diversity within the electorate are correlated, it is necessary to test whether their statistical 
Table 3: Descriptive statistics of turnout in Viennese districts

\begin{tabular}{|c|c|c|c|c|c|c|c|c|c|}
\hline & Year & Min & P25 & P50 & P75 & Max & Mean & SD & $\mathrm{N}$ \\
\hline \multirow{5}{*}{ National elections } & 2006 & 51.06 & 62.74 & 64.45 & 66.72 & 71.02 & 64.40 & 3.95 & 23 \\
\hline & 2008 & 64.60 & 67.33 & 69.69 & 71.74 & 76.70 & 69.94 & 3.16 & 23 \\
\hline & 2013 & 63.04 & 65.73 & 69.20 & 72.35 & 75.51 & 69.01 & 3.65 & 23 \\
\hline & 2017 & 69.18 & 72.47 & 76.07 & 78.78 & 81.53 & 75.67 & 3.95 & 23 \\
\hline & 2019 & 64.70 & 67.76 & 73.11 & 76.20 & 80.38 & 72.28 & 4.85 & 23 \\
\hline \multirow{3}{*}{ Regional elections } & 2005 & 55.52 & 59.46 & 60.23 & 62.10 & 66.53 & 60.81 & 2.41 & 23 \\
\hline & 2010 & 62.76 & 65.82 & 68.26 & 69.77 & 73.27 & 68.06 & 2.75 & 23 \\
\hline & 2015 & 69.26 & 72.50 & 76.06 & 78.04 & 80.97 & 75.38 & 3.44 & 23 \\
\hline \multirow{3}{*}{ European elections } & 2004 & 30.24 & 33.05 & 36.27 & 40.96 & 47.31 & 37.16 & 4.48 & 23 \\
\hline & 2009 & 36.04 & 39.61 & 44.74 & 49.96 & 54.31 & 44.77 & 5.40 & 23 \\
\hline & 2014 & 34.79 & 39.22 & 46.08 & 52.51 & 56.04 & 45.88 & 6.52 & 23 \\
\hline Total & & 30.24 & 52.52 & 66.15 & 71.90 & 81.53 & 62.12 & 13.47 & 253 \\
\hline
\end{tabular}

Note: author's own calculation; Data: Stadt Wien;

associations with aggregate turnout still hold when controlling for covariates.

Table 4 covers six multilevel regressions with predictors added incrementally (Models I-6). The first model is empty and only contains level 2 predictors (elections).
With an intra-class correlation (ICC) of .90, it underlines the necessity of calculating multilevel models (Wenzelburger et al. 20I4, 96). Model 2 contains only controls, showing higher turnout in smaller districts in terms of population size and in districts with a larger proportion

Figure 1: Correlates of district-level turnout in Vienna, 2004-2019
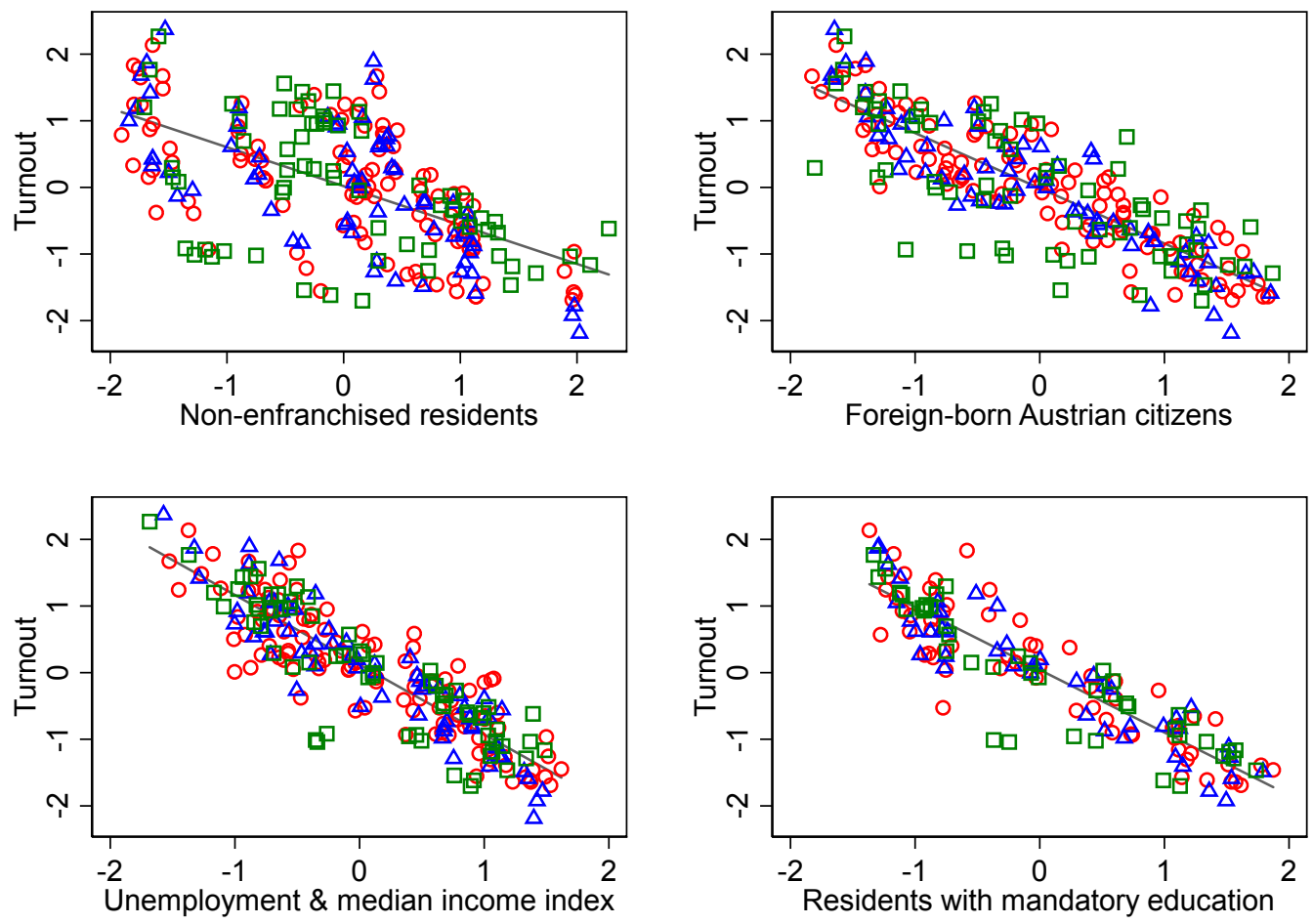

Circle: national election; triangle: regional election; square: European election; Note: all variables standardised per election; first district excluded;

$n=242$ (22 districts over 11 elections), for compulsory education $n=154(22 \times 7)$ 
Table 4: Multilevel regression models on district turnout: random intercept (1-6) and random slope models (7-9)

\begin{tabular}{|c|c|c|c|c|c|c|c|c|c|}
\hline & (1) & (2) & (3) & (4) & (5) & (6) & (7) & (8) & (9) \\
\hline Aged $65+$ years $(\mathrm{std})$ & & $\begin{array}{l}2.26^{* *} \\
(0.38)\end{array}$ & $\begin{array}{l}2.18^{* *} \\
(0.28)\end{array}$ & $\begin{array}{l}1.77^{\star *} \\
(0.26)\end{array}$ & $\begin{array}{l}1.46^{\star *} \\
(0.27)\end{array}$ & $\begin{array}{l}1.23^{* *} \\
(0.33)\end{array}$ & $\begin{array}{l}1.46^{* *} \\
(0.27)\end{array}$ & $\begin{array}{l}1.35^{* *} \\
(0.25)\end{array}$ & $\begin{array}{l}1.35^{\star *} \\
(0.24)\end{array}$ \\
\hline Population size (std log) & & $\begin{array}{c}-2.48^{* *} \\
(0.30)\end{array}$ & $\begin{array}{c}-1.78^{\star *} \\
(0.22)\end{array}$ & $\begin{array}{c}-1.34^{* *} \\
(0.21)\end{array}$ & $\begin{array}{c}-0.89^{* *} \\
(0.25)\end{array}$ & $\begin{array}{c}-0.93^{* *} \\
(0.32)\end{array}$ & $\begin{array}{c}-0.89^{* *} \\
(0.25)\end{array}$ & $\begin{array}{c}-0.74^{* *} \\
(0.23)\end{array}$ & $\begin{array}{c}-0.75^{* *} \\
(0.22)\end{array}$ \\
\hline Population mobility (std) & & $\begin{array}{l}-0.02 \\
(0.28)\end{array}$ & $\begin{array}{l}1.25^{* *} \\
(0.22)\end{array}$ & $\begin{array}{l}0.71^{* *} \\
(0.22)\end{array}$ & $\begin{array}{l}0.53^{*} \\
(0.22)\end{array}$ & $\begin{array}{l}0.60^{*} \\
(0.27)\end{array}$ & $\begin{array}{l}0.53^{*} \\
(0.22)\end{array}$ & $\begin{array}{l}0.40^{*} \\
(0.20)\end{array}$ & $\begin{array}{l}0.39^{*} \\
(0.19)\end{array}$ \\
\hline Left-wing votes (std) & & $\begin{array}{l}-0.13 \\
(0.36)\end{array}$ & $\begin{array}{l}1.33^{* *} \\
(0.28)\end{array}$ & $\begin{array}{l}1.17^{* *} \\
(0.26)\end{array}$ & $\begin{array}{l}1.12^{* *} \\
(0.25)\end{array}$ & $\begin{array}{l}0.92^{* *} \\
(0.32)\end{array}$ & $\begin{array}{l}1.12^{* *} \\
(0.25)\end{array}$ & $\begin{array}{l}1.02^{* *} \\
(0.24)\end{array}$ & $\begin{array}{l}0.98^{* *} \\
(0.24)\end{array}$ \\
\hline Non-enfranchised residents (std) & & & $\begin{array}{c}-2.73^{* *} \\
(0.19)\end{array}$ & $\begin{array}{c}-1.68^{* *} \\
(0.23)\end{array}$ & $\begin{array}{l}-1.12^{\star *} \\
(0.28)\end{array}$ & $\begin{array}{c}-1.38^{\star *} \\
(0.35)\end{array}$ & $\begin{array}{l}-1.12^{\star *} \\
(0.28)\end{array}$ & $\begin{array}{c}-0.89^{* *} \\
(0.26)\end{array}$ & $\begin{array}{c}-0.72^{* *} \\
(0.25)\end{array}$ \\
\hline Foreign-born Austrian citizens (std) & & & & $\begin{array}{c}-1.45^{* *} \\
(0.21)\end{array}$ & $\begin{array}{c}-1.18^{* *} \\
(0.22)\end{array}$ & $\begin{array}{c}-1.20^{* *} \\
(0.30)\end{array}$ & $\begin{array}{l}-1.18^{* *} \\
(0.22)\end{array}$ & $\begin{array}{c}-1.26^{\star *} \\
(0.31)\end{array}$ & $\begin{array}{c}-1.25^{* *} \\
(0.19)\end{array}$ \\
\hline $\begin{array}{l}\text { Unemployment \& median income } \\
\text { index (std) }\end{array}$ & & & & & $\begin{array}{l}-1.32^{* *} \\
(0.39)\end{array}$ & & $\begin{array}{c}-1.32^{* *} \\
(0.39)\end{array}$ & $\begin{array}{c}-1.50^{* *} \\
(0.36)\end{array}$ & $\begin{array}{r}-1.64^{* *} \\
(0.48)\end{array}$ \\
\hline $\begin{array}{l}\text { Unemployment, median income \& } \\
\text { mandatory education index (std) }\end{array}$ & & & & & & $\begin{array}{l}-1.18^{*} \\
(0.50)\end{array}$ & & & \\
\hline Intercept & $\begin{array}{c}62.13^{* *} \\
(3.86)\end{array}$ & $\begin{array}{c}62.60^{* *} \\
(3.87)\end{array}$ & $\begin{array}{c}62.45^{\star *} \\
(3.86)\end{array}$ & $\begin{array}{c}62.32^{* *} \\
(3.87)\end{array}$ & $\begin{array}{c}62.39 * * \\
(3.87)\end{array}$ & $\begin{array}{c}64.27^{* *} \\
(4.64)\end{array}$ & $\begin{array}{c}62.39 * * \\
(3.87)\end{array}$ & $\begin{array}{c}62.39^{* *} \\
(3.87)\end{array}$ & $\begin{array}{c}62.40^{* *} \\
(3.85)\end{array}$ \\
\hline \multicolumn{10}{|l|}{ Random effects } \\
\hline $\begin{array}{l}\text { Level } 2 \text { variance: Non-enfranchised } \\
\text { residents }\end{array}$ & & & & & & & $\begin{array}{l}0.00 \\
0.00\end{array}$ & & \\
\hline $\begin{array}{l}\text { Level } 2 \text { variance: Foreign-born } \\
\text { Austrian citizens }\end{array}$ & & & & & & & & $\begin{array}{l}0.60 \\
(0.31)\end{array}$ & \\
\hline $\begin{array}{l}\text { Level } 2 \text { variance: Unemployment \& } \\
\text { median income index }\end{array}$ & & & & & & & & & $\begin{array}{c}1.25 \\
(0.61)\end{array}$ \\
\hline Variance (election) & $\begin{array}{c}163.17 \\
(69.91)\end{array}$ & $\begin{array}{l}164.05 \\
(70.10)\end{array}$ & $\begin{array}{l}164.03 \\
(70.02)\end{array}$ & $\begin{array}{l}164.33 \\
(70.14)\end{array}$ & $\begin{array}{l}164.22 \\
(70.09)\end{array}$ & $\begin{array}{l}150.84 \\
(80.70)\end{array}$ & $\begin{array}{l}164.22 \\
(70.09)\end{array}$ & $\begin{array}{l}164.27 \\
(70.10)\end{array}$ & $\begin{array}{l}162.69 \\
(69.42)\end{array}$ \\
\hline Variance (residual) & $\begin{array}{c}17.14 \\
(1.60)\end{array}$ & $\begin{array}{l}7.91 \\
(0.74)\end{array}$ & $\begin{array}{c}4.19 \\
(0.39)\end{array}$ & $\begin{array}{l}3.47 \\
(0.32)\end{array}$ & $\begin{array}{c}3.31 \\
(0.31)\end{array}$ & $\begin{array}{c}3.07 \\
(0.36)\end{array}$ & $\begin{array}{c}3.31 \\
(0.31)\end{array}$ & $\begin{array}{c}2.71 \\
(0.26)\end{array}$ & $\begin{array}{c}2.47 \\
(0.24)\end{array}$ \\
\hline $\mathrm{N}$ & 242 & 242 & 242 & 242 & 242 & 154 & 242 & 242 & 242 \\
\hline $\mathrm{N}$ districts & 22 & 22 & 22 & 22 & 22 & 22 & 22 & 22 & 22 \\
\hline $\mathrm{N}$ elections (level 2 ) & 11 & 11 & 11 & 11 & 11 & 7 & 11 & 11 & 11 \\
\hline AIC & 1439.26 & 1268.52 & 1123.82 & 1082.24 & 1073.29 & 678.53 & 1075.29 & 1048.12 & 1031.09 \\
\hline $\mathrm{BIC}$ & 1449.73 & 1292.95 & 1151.73 & 1113.64 & 1108.18 & 708.90 & 1113.67 & 1086.50 & 1069.47 \\
\hline
\end{tabular}

Standard errors in parentheses; ${ }^{*} p<0.05,{ }^{* *} p<0.01$

of residents aged $65+$ years. Adding the percentage of non-enfranchised residents to the model substantially improves model fit (lower aic/bic) and changes the coefficients of two controls: Controlling for electoral exclusion, mobile districts and those with a higher rate of left-wing votes have a significantly higher turnout. The effect of electoral exclusion on aggregate turnout is - as expected - strongly negative and significant. When adding a measure of diversity within the electorate - namely the share of foreign-born Austrian citizens - the statistical effect of electoral exclusion becomes smaller, yet both predictors have significant and negative effects. Adding the index of unemployment and median incomes further increases model fit. Again, the index has a significant and substantial negative effect on turnout. Adding information on the rate of residents with only mandatory education to the index comes at the expense of fewer observations (elections 2008-20I7 only), but does not change the findings substantively in any way (Model 6).

In the next step (Models 7-9), the three predictors of interest are added as random slopes in order to test whether their statistical association with turnout varies across elections. For the index of unemployment and median income and the share of foreign-born Austrian citizens, likelihood-ratio tests suggest adding random slopes. However, the illustrations in Figure 2 indicate that their effects are very similar across elections (fitted lines). Thus, even though random slopes improve the 
Figure 2: Random slopes of regression models 7-9 (fitted lines)
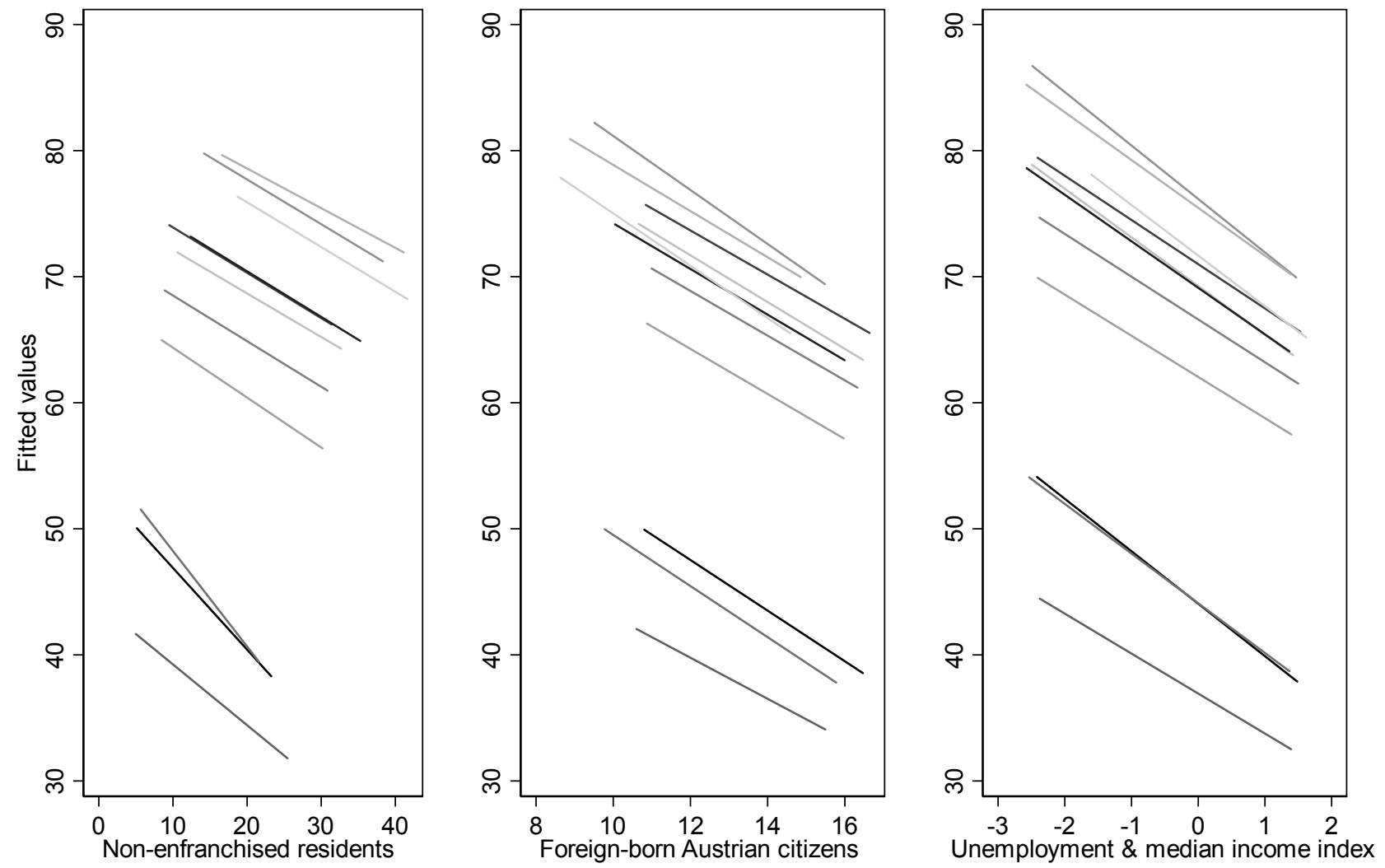

models statistically, they do not alter the main findings in any way: All statistical effects are robust across the eleven elections covered in this analysis.

Since the proportion of non-enfranchised residents, foreign-born Austrian citizens and the index of economic marginalisation correlate (see Table I), it may be necessary to check for a possible interaction effect between these independent variables: Does the effect of electoral exclusion depend on the degree of economic marginalisation? The respective interaction terms of the unemployment and median income index, foreign-born Austrian citizens and non-enfranchised residents in Models IO-I2 do not suggest any such interaction: Model fit decreases and the interaction terms are not significant. Hence, I conclude that the statistical effects of electoral exclusion, diversity within the electorate and economic marginalisation on aggregate turnout are independent.

In contrast to national and regional elections, EU citizens are enfranchised in European elections, but third-country nationals remain excluded. In a separate analysis on European elections only (2004, 2009 and 20I4), the statistical association of non-eligible residents and aggregate turnout should beweaker, because the proportion of excluded residents is much lower. Table 5 lists separate regressions for national and regional elections (Model I3) and European elections (Model I4). While the coefficients for the national/regional election model are very similar to the general models presented before, only the model on European elections is different: diversity within the electorate (foreign-born Austrian citizens), district size, and socio-economic marginalisation are more strongly associated with aggregate turnout in European elections, but the coefficient on the rate of non-enfranchised residents is positive and significant. Obviously, turnout patterns for European elections differ from other elections. However, since the model contains only 66 observations, it should be interpreted with caution.

\subsection{Robustness checks}

Accounting for the nested data structure, the regression models presented above include random intercepts per election and group-mean centred, z-standardised predictors. The residuals (tested for Model 9, Table 4) show an even distribution over different fitted values and over different values of the main independent variables, indicating linear and homoscedastic estimates. Excluding I2 outliers with standardised residuals of $>2$ or $<-2$ does not spoil the substantial results (see Model I7).

When including the first Viennese district in the analysis - which differs substantially from all other districts in terms of its socio-economic profile (very wealthy, few 
Table 5: Multilevel regression models on district turnout: Interaction terms (10-12) and alternative model specifications (13-17)

\begin{tabular}{|c|c|c|c|c|c|c|c|c|}
\hline & \multicolumn{3}{|c|}{ Interaction terms } & \multirow{2}{*}{$\begin{array}{c}\begin{array}{c}\text { National } \\
\text { and regional } \\
\text { elections }\end{array} \\
\text { (13) }\end{array}$} & \multirow{2}{*}{$\begin{array}{c}\begin{array}{c}\text { EP } \\
\text { elections }\end{array} \\
(14)\end{array}$} & \multirow{2}{*}{$\begin{array}{l}\text { Incl. } 1^{\text {st }} \\
\text { district } \\
(15)\end{array}$} & \multirow{2}{*}{$\begin{array}{c}\begin{array}{c}\text { Raw } \\
\text { predictors }\end{array} \\
(16)\end{array}$} & \multirow{2}{*}{$\begin{array}{c}\begin{array}{c}\text { Excluding } \\
\text { outliers }\end{array} \\
(17)\end{array}$} \\
\hline & (10) & (11) & (12) & & & & & \\
\hline \multirow[t]{2}{*}{ Aged 65+ years (std) } & $1.49^{\star \star}$ & $1.34^{\star \star}$ & $1.44^{\star \star}$ & $0.58^{* *}$ & $2.22^{* *}$ & $1.89^{* *}$ & $0.43^{* *}$ & $1.33^{* *}$ \\
\hline & $(0.30)$ & $(0.29)$ & $(0.28)$ & $(0.22)$ & $(0.36)$ & $(0.30)$ & $(0.08)$ & $(0.23)$ \\
\hline \multirow[t]{2}{*}{ Population size (std log) } & $-0.89 * *$ & $-0.91^{* *}$ & $-0.89 * *$ & -0.15 & $-1.82^{* \star}$ & $-0.70^{*}$ & $-1.45^{\star *}$ & $-0.92^{* *}$ \\
\hline & $(0.25)$ & $(0.25)$ & $(0.25)$ & $(0.20)$ & $(0.33)$ & $(0.28)$ & $(0.41)$ & $(0.22)$ \\
\hline \multirow[t]{2}{*}{ Population mobility (std) } & $0.52^{*}$ & $0.55^{\star}$ & $0.51^{*}$ & -0.06 & 0.44 & $0.90^{\star *}$ & $0.14^{\star \star}$ & $0.52^{*}$ \\
\hline & $(0.22)$ & $(0.22)$ & $(0.23)$ & $(0.18)$ & $(0.30)$ & $(0.25)$ & $(0.05)$ & $(0.20)$ \\
\hline \multirow[t]{2}{*}{ Left-wing votes (std) } & $1.13^{* *}$ & $1.09^{* *}$ & $1.12^{\star *}$ & $0.70^{* *}$ & $1.17^{* *}$ & $1.71^{\star \star}$ & $0.18^{* \star}$ & $0.98^{* *}$ \\
\hline & $(0.27)$ & $(0.25)$ & $(0.25)$ & $(0.21)$ & $(0.33)$ & $(0.28)$ & $(0.05)$ & $(0.22)$ \\
\hline \multirow{2}{*}{$\begin{array}{l}\text { Non-enfranchised } \\
\text { residents (std) }\end{array}$} & $-1.12^{* *}$ & $-1.22^{* *}$ & $-1.12^{* *}$ & $-0.60^{* *}$ & $1.38^{* *}$ & $-1.68^{* *}$ & $-0.19^{* *}$ & $-1.14^{\star *}$ \\
\hline & $(0.28)$ & $(0.29)$ & $(0.28)$ & $(0.23)$ & $(0.45)$ & $(0.31)$ & $(0.05)$ & $(0.25)$ \\
\hline \multirow{2}{*}{$\begin{array}{l}\text { Foreign-born Austrian } \\
\text { citizens (std) }\end{array}$} & $-1.18^{\star *}$ & $-1.20^{* *}$ & $-1.19^{\star \star}$ & $-1.63^{\star *}$ & $-1.71^{* *}$ & $-1.89 * *$ & $-0.68^{* *}$ & $-0.98^{\star *}$ \\
\hline & $(0.22)$ & $(0.22)$ & $(0.22)$ & $(0.18)$ & $(0.30)$ & $(0.21)$ & $(0.13)$ & $(0.19)$ \\
\hline \multirow{2}{*}{$\begin{array}{l}\text { Unemployment \& } \\
\text { median income index } \\
\text { (std) }\end{array}$} & $-1.30^{* *}$ & $-1.30^{* *}$ & $-1.33^{* *}$ & $-1.55^{* *}$ & $-3.57^{* *}$ & 0.04 & $-1.39 * *$ & $-1.38^{* *}$ \\
\hline & $(0.40)$ & $(0.39)$ & $(0.40)$ & $(0.31)$ & $(0.60)$ & $(0.40)$ & $(0.38)$ & $(0.34)$ \\
\hline \multirow{2}{*}{$\begin{array}{l}\text { Non-enfranchised } \\
\text { residents (std) X foreign- } \\
\text { born Austrian citizens }\end{array}$} & -0.03 & & & & & & & \\
\hline & $(0.15)$ & & & & & & & \\
\hline \multirow{2}{*}{$\begin{array}{l}\text { Non-enfranchised } \\
\text { residents (std) X } \\
\text { unemployment \& } \\
\text { median income index }\end{array}$} & & 0.19 & & & & & & \\
\hline & & $(0.17)$ & & & & & & \\
\hline \multirow{2}{*}{$\begin{array}{l}\text { Foreign-born Austrian } \\
\text { citizens (std) X } \\
\text { unemployment \& } \\
\text { median income index }\end{array}$} & & & 0.05 & & & & & \\
\hline & & & $(0.18)$ & & & & & \\
\hline \multirow[t]{2}{*}{ Intercept } & $62.41^{\star *}$ & $62.28^{\star *}$ & $62.36^{\star *}$ & $69.64^{* *}$ & $43.08^{\star *}$ & $62.12^{* \star}$ & $72.66^{* *}$ & $62.41^{* *}$ \\
\hline & $(3.87)$ & $(3.87)$ & $(3.87)$ & $(1.67)$ & (2.15) & $(3.86)$ & $(7.54)$ & $(3.89)$ \\
\hline \multirow[t]{2}{*}{ Variance (election) } & 164.14 & 164.49 & 164.18 & 22.14 & 13.73 & 163.59 & 189.93 & 166.64 \\
\hline & $(70.06)$ & $(70.20)$ & $(70.07)$ & (11.10) & $(11.27)$ & $(69.84)$ & (81.39) & $(71.11)$ \\
\hline \multirow[t]{2}{*}{ Variance (residual) } & 3.31 & 3.29 & 3.31 & 1.49 & 1.66 & 4.55 & 3.23 & 2.39 \\
\hline & $(0.31)$ & $(0.31)$ & $(0.31)$ & $(0.16)$ & $(0.30)$ & $(0.41)$ & $(0.30)$ & $(0.23)$ \\
\hline N & 242 & 242 & 242 & 176 & 66 & 253 & 242 & 230 \\
\hline $\mathrm{N}$ districts & 22 & 22 & 22 & 22 & 22 & 23 & 22 & 22 \\
\hline N elections (level 2) & 11 & 11 & 11 & 8 & 3 & 11 & 11 & 11 \\
\hline AIC & 1075.25 & 1074.04 & 1075.23 & 635.85 & 256.29 & 1194.97 & 1069.40 & 953.15 \\
\hline $\mathrm{BIC}$ & 1113.63 & 1112.42 & 1113.61 & 667.55 & 278.18 & 1230.31 & 1104.28 & 987.53 \\
\hline
\end{tabular}

Standard errors in parentheses; ${ }^{*} p<0.05,{ }^{* *} p<0.01$

residents) - the coefficients for non-enfranchised residents and foreign-born Austrian citizens do not change, but the index on unemployment/income becomes insignificant (Model 15). This does not come as a surprise, as the first district has a very high median income level, but low turnout and thereby runs against the general trend.

Using non-standardised, raw predictors (Model I6) contributes to a better model fit and confirms all main results presented above. Since the raw predictors vary more strongly over time (e.g., the proportion of non- enfranchised persons increased substantially over time), this approach deviates from the focus on variation within elections. Hence, group mean-centred models as presented above seem more adequate. 


\section{Discussion}

Even though turnout by and large increased in Vienna over the past II elections, turnout differences aggregated at the district level increased. When Lijphart discusses the implications of turnout for inequality based on social class, he assumes that low turnout is more unequal than high turnout (Lijphart 1997). Surprisingly, in the elections covered in this analysis, heterogeneity increased with turnout, which suggests that participatory inequality is increasingly shaped by spatial context, including socio-economic marginalisation and electoral exclusion (Schäfer et al. 20I3; Bartle et al. 20I7; Förster 2018; Bellettini et al. 20I6). However, how can we interpret such spatial clusters of electoral exclusion and turnout?

\subsection{How may electoral exclusion affect turnout?}

Importantly, the use of aggregate data does not allow a direct inference on the individual level, the interpretation is limited to the level and characteristics of districts (Geys 2006). As such, the analysis shows that districts with lower enfranchisement have lower aggregate turnout, measured by the proportion of non-enfranchised residents of voting age. These findings allow two interpretations: (a) as a spurious correlation, because the degree of electoral exclusion qua citizenship tends to cluster with other contextually relevant factors, such as socio-economic marginalisation; this interpretation cannot be refuted entirely, but the statistical associations between non-enfranchised residents and aggregate turnout is robust against various model specifications and added control variables, rendering a spurious effect unlikely; (b) or the findings can be interpreted as a contagion process in which the presence of electorally excluded individuals inhibits the electoral participation of those who are eligible. Just like voting, also non-voting can be regarded as a social act (Fieldhouse/Cutts 2012; Bhatti/Hansen 2012), for which a lack of voting rights in a neighbourhood may contribute to lower turnout among those who have voting rights. Low-intensity cues of everyday interaction or simple imitation processes might serve as a mechanism for such a contagion process (Cho/Rudolph 2008). Moreover, as voting is fuelled by social pressure (Gerber et al. 2008), such pressure could be lower in a context where fewer people are eligible to vote. Förster (2OI8) takes a somewhat different perspective and highlights social isolation and conflict stemming from ethnic diversity as possible sources for lower turnout in neighbourhoods with high rates of foreign citizen residents in Germany. How the mechanisms behind these statistical effects function is beyond the scope of the data and analysis presented here and calls for further research including individual-level data.

\subsection{Limitations and perspectives for future research}

The main caveat of this analysis certainly lies in its relatively high level of aggregation by using district aggregates. One could argue that a comparison of Viennese districts is not ideal for an investigation of socio-economic and diversity-related context on turnout, because the underlying mechanisms may function at a lower than district level (Förster 2018). Therefore an analysis of smaller administrative units, such as census or election districts (Cho/Rudolph 2008; Bellettini et al. 20I4), may reveal stronger effects of socio-economic marginalisation and electoral exclusion. However, as the analysis shows, differences in turnout for districts with varying degrees of electoral inclusion/exclusion are visible even at a high level of aggregation.

In addition, the approach presented here does not include important individual-level predictors, such as political interest, social networks, or political efficacy (Smets/van Ham 20I3). It is evident that more comprehensive data, based on smaller aggregation units or a combination of individual-level and aggregate-level data would be preferable. Importantly, such individual-level data would have to be geo-coded and cover many observations within small spatial units and hence may be very difficult to obtain. However, given the substantial differences in turnout across Viennese district, the findings presented here call for further research on macro-level determinants of turnout in urban contexts.

These findings contribute to research on electoral rights as well as to research on turnout. On the one hand, this analysis is part of the research on electoral inclusion/exclusion (Pedroza 2015; Blatter et al. 2017; Earnest 2015; Arrighi/Bauböck 2017). Here, scholars of political inclusion/exclusion are primarily focused on policies, but may benefit from evidence on the consequences of electoral rights for participation for the whole of society, not just for electorally excluded individuals. In this vein, Vienna presents an ideal example, but the findings are by no means constrained to this case study. Since cities throughout Europe experience strong demographic changes as a result of immigration (Crul 2016; Trenz/ Triandafyllidou 20I7; Morales/Giugni 20II), the consequences of electoral exclusion for political participation are relevant for metropolitan areas across Europe. For cities, immigrant populations constitute a challenge for input-legitimacy, which requires efforts to stimulate participation in various formats (Stadlmair 2018; Morales/ Giugni 20II). Understanding electoral participation as the core of political membership, many scholars call for an extension of voting rights to permanent residents (Pedroza 2015) or for promoting citizenship acquisition (Bauböck/Perchinig 2006b) in order to dampen spatial heterogeneity of turnout and increase input-legitimacy of democratic polities. The findings of this analysis sug- 
gest effects of electoral exclusion not only for the excluded, but also on the turnout of their co-residents.

On the other hand, distinguishing between immigrants within the electorate (foreign-born Austrian citizens) and residents outside the electorate (third-country nationals, at times EU citizens) allows for disentangling different notions of immigration, diversity and citizenship common in much research on turnout (Wigginton et al. 2020; Cancela/Geys 2016; Smets/van Ham 20I3; Bellettini et al. 20I6; Förster 2018). While the results show that districts with more immigrants within the electorate have substantially lower turnout, there is also some evidence of an effect of foreign residents outside of the electorate.

\section{Conclusion}

Overall, the analysis contributes three insights to the study of spatial differences in aggregate turnout: First, inconclusive findings on immigration and diversity as factors influencing aggregate turnout may be avoided by distinguishing between diversity within the electorate and electoral exclusion qua citizenship (Cancela/Geys 2016; Förster 2018).

Second, the analysis suggests a possible contagion effect of electoral exclusion: Turnout is lower in districts with a high proportion of electorally excluded residents, also when controlling for important contextual covariates such as diversity within the electorate and economic marginalisation. This finding supports theories on social pressure as a driver of turnout (Gerber et al. 2008) and of low-intensity cues for participation (Cho/Rudolph 2008). As such, (non-)voters may respond to observations of (forced) electoral absence with their own absence from elections. Importantly, this effect is driven by the institutional setting of elections and citizenship. Expanding the electorate - as in European elections may limit the relevance of these factors substantially. Thus, there is a twofold 'democratic potential' of enfranchising foreign residents (Pedroza 2015): It gives a voice to otherwise politically marginalised residents and it might affect the participation of their co-residents.

Third, the relevance of such a contagion effect increases in the context of high levels of unenfranchised residents and spatial turnout differences. Since aggregate turnout and electoral exclusion intersect, there are districts in which the ratio between resident population and voting population becomes strongly imbalanced. In 2019, Vienna's I5th district had 77,62I residents, 66,736 of them of voting age, of which 39,246 were enfranchised for the 2019 national elections, of which 25,975or 33 per cent of the total population - effectively participated in the election. This low coverage is concealed by a Vienna-wide turnout rate of 72 per cent. Therefore it is necessary to reflect upon adequate measures for turnout (Wigginton et al. 2020) and de jure inclusion/exclusion should be taken into account when assessing input-legitimacy of elections.

\section{References}

Arrighi, Jean-Thomas/Rainer Bauböck (2017), A multilevel puzzle: Migrants' voting rights in national and local elections, in: European Journal of Political Research, Vol. 56(3), 619-639.

Bartle, John/Sarah Birch/Mariana Skirmuntt (2017), The local roots of the participation gap: Inequality and voter turnout, in: Electoral Studies, Vol. 48, 30-44.

Bauböck, Rainer (2018), Democratic inclusion: Rainer Bauböck in dialogue, Manchester: Manchester University Press.

Bauböck, Rainer/Bernhard Perchinig (2006a), Migrationsund Integrationspolitik, in: Dachs, Herbert/Peter Gerlich/Herbert Gottweis/Helmut Kramer/Volkmar Lauber/Wolfgang C. Müller/Emmerich Tálos (eds.), Politik in Österreich: Das Handbuch, Wien: Manz, 726-742.

Bauböck, Rainer/Bernhard Perchinig (2006b), Evaluation and Recommendations, in: Bauböck, Rainer/Eva Ersbøll/Kees Groenendijk/Harald Waldrauch (eds.), Acquisition and Loss of Nationality: Policies and Trends in I5 European States. Volume I: Comparative Analyses, Amsterdam: Amsterdam University Press, 43I-478.

Bellettini, Giorgio/Carlotta Berti Ceroni/Chiara Monfardini (20I4), Socio-Economic Heterogeneity and Electoral Turnout: An Aggregate Analysis with Precinct-Level Data, CESifo Working Paper 4999, Internet: https:// ideas.repec.org/p/ces/ceswps/_4999.html (Access: 02/06/2020).

Bhatti, Yosef/Kasper Møller Hansen (2012), Leaving the Nest and the Social Act of Voting: Turnout among First-Time Voters, in: Journal of Elections, Public Opinion and Parties, Vol. 22(4), 380-406.

Bird, Karen/Thomas Saalfeld/Andreas Wüst (eds.) (20II), The political representation of immigrants and minorities: voters, parties and parliaments in liberal democracies, Abingdon/New York: Routledge.

Blatter, Joachim/Samuel Schmid/Andrea Blättler (2017), Democratic Deficits in Europe: The Overlooked Exclusiveness of Nation-States and the Positive Role of the European Union, in: Journal of Common Market Studies, Vol. 55(3), 449-467.

Bodlos, Anita/Carolina Plescia (2018), The 2017 Austrian snap election: a shift rightward, in: West European Politics, Vol. 4I(6), I354-I363.

Cancela, João/Benny Geys (2016), Explaining voter turnout: A meta-analysis of national and subnational elections, in: Electoral Studies, Vol. 42, 264-275. 
Caren, Neal (2007), Big City, Big Turnout? Electoral Participation in American Cities, in: Journal of Urban Affairs, Vol. 29(I), 3I-46.

Cho, Wendy (1999), Naturalization, Socialization, Participation: Immigrants and (Non-) Voting, in: The Journal of Politics, Vol. 6I(4), II4O-II55.

Cho, Wendy/Thomas Rudolph(2008), Emanating Political Participation: Untangling the Spatial Structure Behind Participation, in: British Journal of Political Science, Vol. 38(2), 273-289.

Crul, Maurice (2016), Super-diversity vs. assimilation: how complex diversity in majority-minority cities challenges the assumptions of assimilation, in: Journal of Ethnic and Migration Studies, Vol. 42(I), 54-68.

Dolezal, Martin/Eva Zeglovits (2014), Almost an Earthquake: The Austrian Parliamentary Election of 20I3, in: West European Politics, Vol. 37(3), 644-652.

Earnest, David (2015), Expanding the Electorate: Comparing the Noncitizen Voting Practices of 25 Democracies, in: Journal of International Migration and Integration, Vol. I6(I), I-25.

Fieldhouse, Edward/David Cutts (2012), The Companion Effect: Household and Local Context and the Turnout of Young People, in: The Journal of Politics, Vol. 74(3), 856-869.

Förster, André (2018), Ethnic heterogeneity and electoral turnout: Evidence from linking neighbourhood data with individual voter data, in: Electoral Studies, Vol. 53, 57-65.

Gerber, Alan/Donald Green/Christopher Larimer (2008), Social Pressure and Voter Turnout: Evidence from a Large-Scale Field Experiment, in: American Political Science Review, Vol. IO2(I), 33-48.

Geys, Benny (2006), Explaining voter turnout: A review of aggregate-level research, in: Electoral Studies, Vol. 25(4), 637-663.

Hooghe, Marc/Anna Kern (2017), The tipping point between stability and decline: Trends in voter turnout, 1950-1980-2012, in: European Political Science, Vol. I6(4), 535-552.

Hopkins, Daniel/Thad Williamson (2012), Inactive by Design? Neighborhood Design and Political Participation, in: Political Behavior, Vol. 34(I), 79-IOI.

Hudson, Irene/Linda Moore/Eric Beh/David Steel (20I0), Ecological Inference Techniques: An Empirical Evaluation Using Data Describing Gender and Voter Turnout at New Zealand Elections, I893-I919, in: Journal of the Royal Statistical Society, Vol. I73(I), I85-2 I3.

Just, Aida/Christopher Anderson (20I2), Immigrants, Citizenship and Political Action in Europe, in: British Journal of Political Science, Vol. 42(3), 48I-509.

King, Gary (1997), A solution to the ecological inference problem, Princeton: Princeton University Press.
Lijphart, Arend (1997), Unequal Participation: Democracy's Unresolved Dilemma, in: American Political Science Review, Vol. 9I(I), I-I4.

Morales, Laura/Marco Giugni (eds.) (20II), Social Capital, Political Participation and Migration in Europe, Basingstoke: Palgrave.

Nickerson, David (2008), Is Voting Contagious? Evidence from Two Field Experiments, in: American Political Science Review, Vol. IO2(I), 49-57.

Pedroza, Luicy (2015), The Democratic Potential of Enfranchising Resident Migrants, in: International Migration, Vol. 53(3), 22-35.

Poier, Klaus (2009), Postal Voting in Austria - First Experiences from a Law and Political Science Perspective, in: ICL Journal, Vol. 3(4), 255-267.

Ruedin, Didier (2018), Participation in Local Elections: Why Don't Immigrants Vote More?, in: Parliamentary Affairs, Vol. $7 \mathrm{I}(2)$, 243-262.

Schäfer, Armin (20I3), Wahlbeteiligung und Nichtwähler, in: Aus Politik und Zeitgeschichte, Vol. 48-49, 39-46.

Schäfer, Armin/Robert Vehrkamp/Jérémie Gagné (2013), Prekäre Wahlen: Milieus und soziale Selektivität der Wahlbeteiligung bei der Bundestagswahl, Gütersloh: BertelsmannStiftung.

Siegel, David (2009), Social Networks and Collective Action, in: American Journal of Political Science, Vol. 53(I), I22-I38.

Smets, Kaat/Carolien van Ham (2013), The embarrassment of riches? A meta-analysis of individual-level research on voter turnout, in: Electoral Studies, Vol. 32(2), 344-359.

Stadlmair, Jeremias (20I8), Demokratische Mitbestimmung von Fremden aus politikwissenschaftlicher Perspektive, in: Salzburger Landtag/Katharina Weiser (eds.), Demokratische Zukunft der (Salzburger) Landesgesetzgebung: Festschrift Ioo Jahre Erste Republik, Wien: Jan Sramek Verlag, I2 I-I55.

Stern, Joachim/Gerd Valchars (20I3), Access to Electoral Rights: Austria, San Domenico di Fiesole: EUDO Citizenship Observatory.

Straits, Bruce (1990), The Social Context of Voter Turnout, in: Public Opinion Quarterly, Vol. 54(I), 64-73.

Street, Alex (20I7), The Political Effects of Immigrant Naturalization, in: International Migration Review, Vol. 5I(2), 323-343.

Trenz, Hans-Jörg/Anna Triandafyllidou (20I7), Complex and dynamic integration processes in Europe: intra EU mobility and international migration in times of recession, in: Journal of Ethnic and Migration Studies, Vol. 43(4), 546-559.

Vallbé, Joan-Josep/Jaume Magre Ferran (2017), The Road Not Taken. Effects of residential mobility on local electoral turnout, in: Political Geography, Vol. 60, 8699. 
Verba, Sidney/Kay Schlozman/Henry Brady (1995), Voice and Equality: Civic Voluntarism in American Politics, Cambridge: Harvard University Press.

Vonnahme, Greg (2012), Registration Deadlines and Turnout in Context, in: Political Behavior, Vol. 34(4), 765-779.

Wass, Hanna/André Blais/Alexandre Morin-Chassé/Marjukka Weide (2015), Engaging Immigrants? Examining the Correlates of Electoral Participation among Voters with Migration Backgrounds, in: Journal of Elections, Public Opinion and Parties, Vol. 25(4), 407-424.

Wenzelburger, Georg/Sebastian Jäckle/Pascal König (2014), Weiterführende statistische Methoden für Politikwissenschaftler: Eine anwendungsbezogene Einführung mit Stata, Oldenburg: de Gruyter.

Wigginton, Michael/Daniel Stockemer/Jasmine van Schouwen (2020), International Migration and Turnout Bias, in: PS: Political Science \& Politics, online first, 33-38.

Wilford, Allan (2019), Turnout, party system diversity and left-of-centre parties: explaining turnout through the strength of left-of-centre parties, in: European Political Science, Vol. I8(I), 66-83.

Wineroither, David/Herbert Kitschelt (2012), Die Entwicklung des Parteienwettbewerbs in Österreich im internationalen Vergleich, in: Helms, Ludger /David Wineroither (eds.), Die österreichische Demokratie im Vergleich, Baden-Baden: Nomos, 193-221.

Zeglovits, Eva/Julian Aichholzer (2014), Are People More Inclined to Vote at 16 than at 18 ? Evidence for the First-Time Voting Boost Among 16- to 25-Year-Olds in Austria, in: Journal of Elections, Public Opinion and Parties, Vol. 24(3), 35I-36I.

\section{Author}

Dr. Jeremias Stadlmair is assistant professor (Universitätsassistent) at the Department of Political Science at the University of Vienna and chairperson of the Austrian Political Science Association (AuPSA/OEGPW). His research focuses on political participation, the politics of citizenship and democratic innovations. 
